\title{
Elicitation of antioxidant metabolites in Musa species in vitro shoot culture using sucrose, temperature and jasmonic acid
}

\author{
Ibukun O. Ayoola-Oresanya ${ }^{1,2,3} \cdot$ Mubo A. Sonibare ${ }^{1} \cdot$ Badara Gueye $^{2}\left({ }^{(0)} \cdot\right.$ Michael T. Abberton $^{2} \cdot$ Gertrud E. Morlock $^{3}$
}

Received: 8 September 2020 / Accepted: 17 March 2021 / Published online: 4 April 2021

(c) The Author(s) 2021

\begin{abstract}
In vitro culture is not only known for the mass propagation of medicinal plants, it can also be used to boost the accumulation of useful metabolites. This work was aimed at studying the potential of elicitation on the accumulation of antioxidant secondary metabolites in different Musa species accessions. Shoot cultures of selected six Musa spp. accessions were micropropagated on Murashige and Skoog mineral-based culture medium, supplemented with indole-3-acetic acid and 6-benzylaminopurine. Different temperatures $\left(15,20\right.$ and $\left.26^{\circ} \mathrm{C}\right)$, doses of sucrose $(30-50 \mathrm{~g} / \mathrm{L})$ and jasmonic acid concentrations (JA, 50-200 $\mu \mathrm{M}$ ) were used as elicitors in the culture medium. High-performance thin-layer chromatography (HPTLC) coupled with effect-directed analysis (EDA) was used to compare and characterize all the 71 Musa spp. samples from the selected accessions and to reveal compound zones with antioxidant, antidiabetic and anticholinesterase activities. All elicitation and plant tissue culture experiments increased the total phenolic content (TPC) and antioxidant activity of the selected Musa spp. accessions. Extracts from plants grown at $20^{\circ} \mathrm{C}$ gave the highest TPC and antioxidant activity. Addition of JA $(200 \mu \mathrm{M})$ and higher sucrose contents ( $40 \mathrm{~g} / \mathrm{L}$ or $45 \mathrm{~g} / \mathrm{L}$ ) increased the TPC and antioxidant activity as well. Not only compounds with antioxidant, but also antidiabetic and anticholinesterase activities were detected in the elicited accessions. The system presented in this study could serve as a sustainable, consistent and reliable alternative means of bioactive metabolites supply for the production of biopharmaceuticals.
\end{abstract}

\section{Key message}

Antioxidant and phenolic content in Musa spp. can be increased by growing Musa shoot cultures at $20^{\circ} \mathrm{C}$, adding sucrose at 40 or $45 \mathrm{~g} / \mathrm{L}$ and jasmonic acid $(200 \mu \mathrm{M})$.

Keywords Elicitation · Musa species · Bioactive metabolites · HPTLC · Antioxidant · Anticholinesterase · Antidiabetic

\begin{tabular}{l} 
Abbreviations \\
DPPH $\quad$ 2,2-Diphenyl-1-picrylhydrazyl \\
EDA $\quad$ Effect-directed analysis \\
FLD $\quad$ Fluorescence detection \\
GAE $\quad$ Gallic acid equivalent \\
$h R_{\mathrm{F}} \quad$ Homologous retention factor $\left(\mathrm{R}_{\mathrm{f}} \times 100\right)$ \\
\hline Communicated by Bart Panis. \\
\hline $\begin{array}{l}\text { Badara Gueye } \\
\text { B.Gueye @ cgiar.org }\end{array}$ \\
$\begin{array}{l}\text { Department of Pharmacognosy, Faculty of Pharmacy, } \\
\text { University of Ibadan, Ibadan, Nigeria }\end{array}$ \\
Genetic Resources Centre, International Institute of Tropical \\
Agriculture, Ibadan, Nigeria \\
Chair of Food Science, Institute of Nutritional Science, \\
Justus Liebig University, Giessen, Germany
\end{tabular}

HPTLC High-performance thin layer chromatography

JA Jasmonic acid

TPC Total phenolic content

UV/Vis Ultraviolet/visible

\section{Introduction}

In the exploration for new plant-based bioactive secondary metabolites, constant supply of plant material remains a need in the endeavours towards continuous and sustainable preservation and rational usage of biodiversity (Karuppusamy 2009). The importance and expanding commercial use of plant secondary metabolites has led to a great increase in plant bioactive metabolites production, using in vitro plant tissue culture systems. Several secondary metabolites have been produced using in vitro plant tissue culture systems. 
For example, camptothecin, a monoterpene indole alkaloid was produced from cell suspension culture of Camptotheca acuminata Decne (Pi et al. 2010). Taraxerol and taraxasterol, anticancer compounds were produced from the root callus suspension culture of Taraxacum officinale Weber (Sharma and Zafar 2016). Also, in vitro plant tissue culture system has been reported as one of the notable means for commercial production of artemisinin, the antimalaria and anticancer drug (Kayani et al. 2018). Regeneration of plants via in vitro propagation has a remarkable potential for the production of synchronized, controlled and high-quality plant materials, as a means for large-scale production of medicinal compounds. With the increasing market demand for novel plants products, in vitro culture became a reliable tool for the steady and mass production of plant materials (Hussain et al. 2012).

Research in the pharmaceutical and food industries has focused on developing new techniques that allow secondary metabolites production from in vitro plant tissue culture (Anand 2010). Producing bioactive compounds from this plant tissue culture method is less expensive than extraction from the whole field-grown plant under natural conditions or making them through artificial synthesis. Moreover, this in vitro technique allows the manipulation of the biosynthetic routes to increase the production and accumulation of specific compounds (Dias et al. 2016). One of the means to increase the production of secondary metabolites using in vitro plant cell or tissue cultures is called elicitation.

Elicitation can be defined as an effective and a notable method for the enhancement and generation of numerous commercially useful medicinal compounds from plants (Perassolo et al. 2011). Elicitors are signals or molecules triggering the formation of secondary metabolites. The elicitation process occurs in response to stress stimuli that activate the protective mechanisms of the plants via secondary metabolite biosynthesis (Rea et al. 2011). The use of elicitors for producing numerous secondary metabolites has been reported in many plants species (Narayani and Srivastava 2017; Thakur et al. 2019). An abiotic elicitor, cobalt nitrate, was used to increase ginsenoside production by two folds compared to the control in suspension culture of Panax quinquefolius (Biswas et al. 2016). Yeast extract and silver nitrate $\left(\mathrm{AgNO}_{3}\right)$ were used as elicitors in suspension culture of Ophiorrhiza mungos Linn. and resulted in 13.3-fold and 8.7-fold increment in camptothecin production when yeast extract $(50 \mathrm{mg} / \mathrm{L})$ and $\mathrm{AgNO}_{3}(2.5 \mu \mathrm{M}$ ) were used as elicitors, respectively (Deepthi and Satheeshkumar 2015). Other examples of elicitors used to enhance secondary metabolites production in plant tissue culture include; carbohydrates (sucrose, mannan, chitosan, chitin), light irradiation, nutrient stress, salicylic acid and jasmonic acid among others (Thakur et al. 2019). Temperature, sucrose and jasmonic acid (JA) were used as elicitors in this study. Jasmonic acid is an endogenous plant hormone also known as a signaling molecule. It is involved in plant stress response (Afrin et al. 2015) that stimulates the biosynthesis and accumulation of secondary metabolites in plants (Pauwels et al. 2009). Apart from the fact that sucrose is one of the nutrients that provides energy and serves as carbon source, it can also affect the physiological activities and metabolism during plant in vitro growth and used as an elicitor. Increasing sucrose content in the in vitro culture medium has been reported to increase the accumulation of phenolic compounds in plants (Fazal et al. 2016).

Musa spp. has many medicinal applications with interesting metabolites. They have been reported for pharmacological activities such as wound healing (Rosida et al. 2014), antidiabetic (Vilhena et al. 2018), antiulcer (Abdullah et al. 2014), antimicrobial (Umamaheswari et al. 2017) and antioxidant (Sonibare et al. 2018), containing many flavonoids and phenolic compounds. Its amenability to in vitro plant tissue culture techniques makes it a good candidate for supply of phytochemicals. Previous study showed that Musa spp. leaves had higher phenolic content and antioxidant activity than the fruits (Ayoola et al. 2017). The in vitro-grown leaves were found to contain more phenolic compounds as revealed from highperformance thin layer chromatography analysis, and higher total phenolic content measured as gallic acid equivalent per weight of plant extract as well as higher antioxidant activity than the field-grown ones in all studied accessions (AyoolaOresanya et al. 2020). Recently, an anticholinergic alkaloid was detected only from in vitro-grown Musa spp. samples, using high-performance thin-layer chromatography (HPTLC) hyphenated with high-resolution mass-spectrometry (HRMS) (Ayoola-Oresanya et al. 2020). High-performance thin-layer chromatography is a reliable, efficient and accurate technique for the bioprofiling of complex samples, allowing the parallel qualitative and quantitative analysis of up to 20 samples. It allows the application of crude extracts and the coupling with bioassays using effect-directed analysis (EDA) as well as spectroscopic and spectrometry techniques (Morlock and Schwack 2010).

This research presents the first elicitation study of antioxidant metabolites obtained from in vitro shoot cultures of six different Musa species accessions. Various plant tissue culture parameters, i.e. the effect of temperature, nutrient stress and JA addition were explored to increase the accumulation of secondary metabolites, especially on the accessions previously identified to have relatively low phenolic content and antioxidant activity. 


\section{Materials and methods}

\section{Plant materials and micropropagation conditions for six Musa species accessions}

Six Musa species accessions were selected from the Taxonomical Reference Collection, which are representatives of the global Musa biodiversity (Drapal et al. 2019), at the Genetic Resource Centre, International Institute of Tropical Agriculture, Ibadan, Nigeria (Table 1). Two accessions with high antioxidant activity (Simili radjah and Foconah), two with moderate activity (P. Mas and Red Dacca) and two with low antioxidant activity (Dole and M. balbisiana HND), were selected based on the results from a previous study on the total phenolic content (TPC) and antioxidant activity of fifteen taxonomic reference accessions (AyoolaOresanya et al. 2020). Invitro-grown plantlets, established from meristem culture, served as explants for the experiments. They were first multiplied on the liquid proliferation media without the solidifying agent gelrite, using the temporary immersion system and RITA $®$ apparatus, as reported by Jekayinoluwa et al. (2019). The temporary immersion system was used for mass multiplication of the plant material, resulting in about 25 shoots per system. The shoots were then transferred to a semi-solid culture medium containing $2.5 \mathrm{~g} / \mathrm{L}$ of gelrite. The Murashige and Skoog (MS) mineralbased culture medium was used for banana shoot proliferation (Murashige and Skoog 1962; Gueye et al. 2012; Ayoola et al. 2017), supplemented with $30 \mathrm{~g} / \mathrm{L}$ sucrose, $0.1 \mathrm{~g} / \mathrm{L}$ myoinositol, $10 \mathrm{mg} / \mathrm{L}$ ascorbic acid, $0.18 \mathrm{mg} / \mathrm{L}$ indole-3-acetic acid and $4.5 \mathrm{mg} / \mathrm{L}$ 6-benzylaminopurine. Gelrite $(2.5 \mathrm{~g} / \mathrm{L})$ was used as gelling agent. The $\mathrm{pH}$ of the culture media was adjusted to 5.7 prior autoclaving at $121{ }^{\circ} \mathrm{C}, 100 \mathrm{kPa}$ for $15 \mathrm{~min}$. The cultures were maintained in the culture room at $25 \pm 1{ }^{\circ} \mathrm{C}$, with a $12 \mathrm{~h} \mathrm{light} / 12 \mathrm{~h}$ dark photoperiod given by cool white fluorescent lamps at $38 \mu \mathrm{mol} / \mathrm{m}^{2} / \mathrm{s}$.

\section{Elicitation experiments}

Sucrose content, temperature and JA were used as elicitors in the in vitro shoot cultures of the selected six Musa spp. accessions. The effect of the three elicitors on the production of antioxidant compounds was determined at different doses in the culture medium. All the elicitation experiments were done in replicates. The shoots were harvested at the end of the experiment and kept at $-80{ }^{\circ} \mathrm{C}$ for phenolic compound quantification and evaluation of the antioxidant activity.

\section{Increase in sucrose level}

The Murashige and Skoog mineral-based culture medium for shoot induction was supplemented with $35,40,45$ and $50 \mathrm{~g} / \mathrm{L}$ of sucrose. Culture media with $30 \mathrm{~g} / \mathrm{L}$ of sucrose was used as control. In vitro-grown explants were sub-cultured on different in vitro culture media and kept in the growth chamber $\left(\mathrm{T}^{\circ} 25 \pm 1{ }^{\circ} \mathrm{C}, 12 \mathrm{~h}\right.$ light $/ 12 \mathrm{~h}$ dark light: $38 \mu \mathrm{mol} /$ $\mathrm{m}^{2} / \mathrm{s}$ ). The experiment was done in replicates and the growth parameters measured weekly for a period of 6 weeks.

\section{Temperature reduction}

The Musa spp. plantlets were sub-cultured on the routine proliferation media as described above, but kept in different temperature conditions, i.e. $26 \pm 2{ }^{\circ} \mathrm{C}$ (control), $20 \pm 2{ }^{\circ} \mathrm{C}$ and $15 \pm 2{ }^{\circ} \mathrm{C}$; using plant growth cabinet (Percival Scientific Perry, USA). These temperature conditions were monitored with a temperature logger. Growth parameters were measured over a period of 8 weeks due to the slow growth of the plants at reduced temperature.

\section{Addition of JA}

Different concentrations of this abiotic elicitor JA (50, 100 and $200 \mu \mathrm{M}$ ) were added separately to the Musa spp. proliferation culture media. The effect on the secondary metabolite production was investigated. Plantlets of Musa spp. exposed to Murashige and Skoog mineral-based culture medium without any elicitor served as control.

\section{Statistical analysis}

The growth parameters (number of shoots, number of leaves, shoot length and number of roots) for the different experiments were collected on all the cultured plantlets and analyzed using SAS statistical package. Results are
Table 1 List of the selected six accessions from the Taxonomical Reference Musa spp. collection

\begin{tabular}{llllll}
\hline ID & TRC accession & ITC code & Species & Genome group & Origin \\
\hline 1 & Simili Radjah & ITC.0123 & Musa acuminata & ABB & Cote d'Ivore \\
2 & Foconah & ITC.0649 & Musa acuminata & AAB & Unknown \\
3 & Pisang Mas & ITC.0653 & Musa acuminata & AA & Unknown \\
4 & Red Dacca & ITC.0575 & Musa acuminata & AAA & Unknown \\
5 & Dole & ITC.0767 & Musa acuminata & ABB & Unknown \\
6 & Musa balbisiana HND & ITC.0080 & Musa balbisiana & BBwild & Honduras \\
\hline
\end{tabular}


expressed as the mean \pm standard error of mean (SEM) of 20 samples. One-way ANOVA at $\mathrm{P}<0.05$ was used to test the significance difference of data followed by Tukey's multiple comparison of means.

\section{HPTLC-UV/Vis/FLD-EDA method}

\section{Extraction}

The 71 Musa spp. samples of the elicitation experiments, collected from the studied accessions, were freeze-dried, grinded and kept in an airtight container. Powdered samples were weighed into $1.5-\mathrm{mL}$ Eppendorf tubes and extracted $(1 \mathrm{mg} / \mathrm{mL})$. Four different extraction solvent polarities were investigated (methanol, ethanol-water 7:3, ethyl acetate and $n$-hexane). Ethanol-water 7:3 was selected, as it extracted most compounds (Fig. S-6). The samples were vortexed, sonicated for $10 \mathrm{~min}$, centrifuged at $900 \times \mathrm{g}$ for $30 \mathrm{~min}$ and filtered into $1.8 \mathrm{~mL}$ sampler vials.

\section{Chromatographic system}

Respective extract solutions were sprayed depending on the number of tracks needed on the HPTLC plates at an 8-mm distance from the bottom edge (ATS 4, CAMAG, Muttenz, Switzerland). For the temperature experiment, 18 extract solutions $(1.5 \mu \mathrm{L} / \mathrm{band}, 600 \mathrm{ng} / \mathrm{band})$ were applied as $8-\mathrm{mm}$ bands with a track distance of $10 \mathrm{~mm}$. The JA experiment took 23 extract solutions $(1.0 \mu \mathrm{L} / \mathrm{band}$, $400 \mathrm{ng} / \mathrm{band}$ ) applied as 6.5 -mm bands with a track distance of $8.2 \mathrm{~mm}$. For the sucrose experiments, 30 extract solutions $(1.0 \mu \mathrm{L} / \mathrm{band}, 1000 \mathrm{ng} / \mathrm{band})$ were applied as 8-mm bands on two HPTLC plates with a track distance of $10 \mathrm{~mm}$ (15 samples/plate). The HPTLC plate was developed with a polar acidic mobile phase, consisting of ethyl acetate-toluene-formic acid-water, 6.8:1:1.4:1 (V/V/V/V). This took $30 \mathrm{~min}$ up to a migration distance of $60 \mathrm{~mm}$ in an unsaturated $20 \mathrm{~cm} \times 10 \mathrm{~cm}$ Twin Trough Chamber. The chromatogram was documented at white light illumination (Vis), UV $254 \mathrm{~nm}$ (UV) and Fluorescence detection (FLD) $366 \mathrm{~nm}$ (FLD; TLC Visualizer, CAMAG). The densitometric absorbance measurement was performed at $546 \mathrm{~nm}$ using the mercury lamp and an inverse scan mode (fluorescence mode without optical filter, TLC Scanner 4, CAMAG). For the TPC study, the results were equivalently calculated as gallic acid equivalents (GAE) by linear regression referred to four or five different gallic acid levels (3-30 $\mu \mathrm{L} / \mathrm{band}, 10-100 \mathrm{ng} / \mathrm{band}$ ), as reported. Instruments were operated and data evaluated using the winCATS software version 1.4.7.2018 (CAMAG).

\section{Effect-directed assays}

Before the respective assay performance, few microliters of a respective positive control solution (e.g., $0.1 \mathrm{mg} / \mathrm{mL}$ gallic acid, $0.1 \mathrm{mg} / \mathrm{mL}$ physostigmine, $1 \mathrm{mg} / \mathrm{mL}$ acarbose and $0.1 \mathrm{mg} / \mathrm{mL}$ nitroquinoline-1-oxide) were applied on each plate. For the radical scavenging (antioxidant) assay, the chromatograms were dipped in a $0.2 \%$ methanolic 2,2-diphenyl-1-picrylhydrazyl (DPPH) solution (immersion speed $3 \mathrm{~cm} / \mathrm{s}$, immersion time $2 \mathrm{~s}$, TLC Immersion Device, CAMAG) and documented under white light illumination after 1,10 and $30 \mathrm{~min}$. The HPTLC- $\alpha$-glucosidase inhibition assay was performed by piezoelectric spraying (Derivatizer, CAMAG) according to Jamshidi-Aijdi et al. (2019). Concisely, first $2 \mathrm{~mL}$ substrate solution (60 mg 2-naphtyl$\alpha$-D-glucopyranoside in $50 \mathrm{~mL}$ ethanol) were sprayed on the neutralized chromatogram, then after air-drying $(2 \mathrm{~min})$, $1 \mathrm{~mL}$ sodium acetate buffer ( $\mathrm{pH} 7.2-7.5)$ for pre-wetting and $2 \mathrm{~mL} \alpha$-glucosidase solution (from Saccharomyces cerevisiae, $500 \mathrm{U}$ in $50 \mathrm{~mL}$ buffer). After incubation of the plate placed horizontally in a pre-prepared humidity box at $37{ }^{\circ} \mathrm{C}$ for $13 \mathrm{~min}, 0.5 \mathrm{~mL}$ Fast Blue Salt B solution was sprayed on the chromatogram and documented under white light illumination after drying (ADC2 humidity control, CAMAG). Analogously, the HPTLC-acetylcholinesterase assay (Azadniya and Morlock 2018) and HPTLC-SOS-Umu-C bioassay (Meyer et al. 2021) were performed.

\section{Results and discussion}

For the six accessions, the different elicitation experiments resulted in 18, 30 and 23 samples were harvested from the temperature decrease, the sucrose increase and JA addition experiments, respectively. The M. balbisiana HND accession treated with $50 \mu \mathrm{M} \mathrm{JA}$ did not grow, and thus one sample is missing. All elicitation experiments resulted in 71 different plant samples from different treatments and accessions. Effects of the different treatments on the vegetative growth of the Musa spp. accessions were determined (Fig. 1). After freeze-drying, grinding and extraction, an HPTLC method revealed the antioxidant profile and the accumulation of antioxidant compounds (Figs. 2, 3).

\section{Effect of sucrose increase on growth parameters and antioxidant activity}

The increase of sucrose in the culture medium from 30 to $45 \mathrm{~g} / \mathrm{L}$ led to more leaf initiation in some in vitro materials of Musa spp., such as Simili radjah and M. balbisiana HND (Fig. 1b). It also increased the number of shoots in most accessions. Particularly, the addition of 40 and $45 \mathrm{~g} / \mathrm{L}$ of sucrose had a more notable favourable effect on the average 


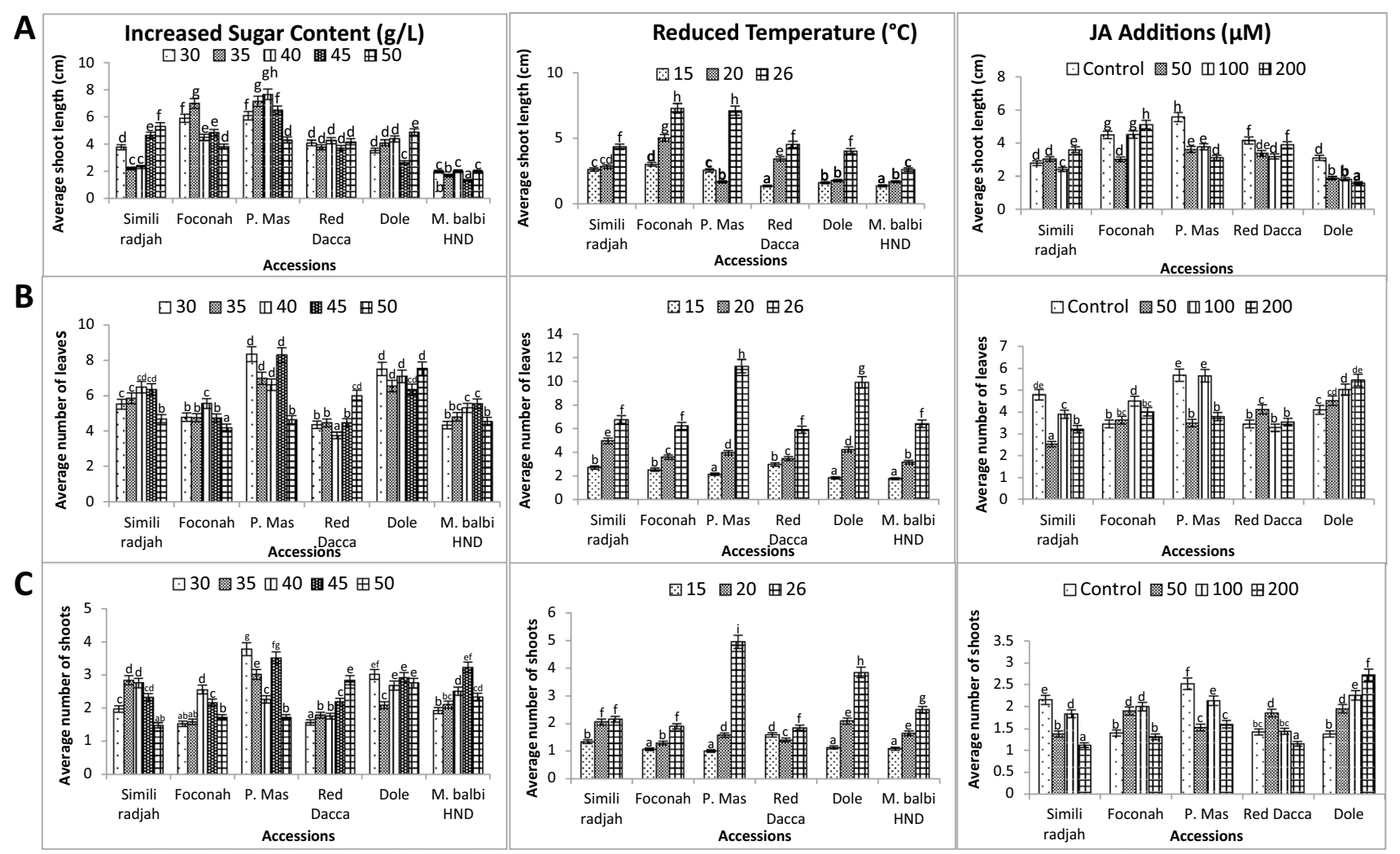

Fig. 1 Growth parameters at the end of 6 weeks of incubation of the six different Musa spp. accessions grown under increased sucrose content, reduced temperature and JA additions: a average shoot length, $\mathbf{b}$ average number of leaves and $\mathbf{c}$ average number of shoots. Data are presented as mean \pm Standard error (SE) of 20 replicates. Means with the same alphabets are not statistically different at $P<0.05$

Antioxidant signal, along with TPC, amplified with increasing sucrose doses across all accessions, with 40 and $50 \mathrm{~g} / \mathrm{L}$ giving the highest activity (Table 2), although a similar compound zone pattern was observed. For the accession Foconah, TPC increased most, by 4.9 -fold from $39.4 \mathrm{ng} / \mathrm{g}$ GAE (30 g/L) to $138.6 \mathrm{ng} / \mathrm{g}$ GAE (50 g/L), whereas the increase was 1.2- to 2.8-fold for other accession extracts. Ali et al. (2016) reported that total phenolic content increased sequentially with increase in sucrose concentration from 1 to $5 \%$ in the cell suspension cultures of Artemisia absinthium L. Other studies have also reported an increase in the TPC when higher doses of sucrose were added to culture media (Wu et al. 2006; Cui et al. 2010), as sucrose may induce osmotic stress, which can in turn increase the accumulation of phenolics in plant cells (Suan See et al. 2011).

\section{Effect of temperature reduction on formation of antioxidative metabolites}

The three different temperature conditions studied $(15,20$ and $26^{\circ} \mathrm{C}$ ) had an impact on the growth rate and accumulation of antioxidative compounds. The lower the temperature detecte as bright bands on a purple background in the 


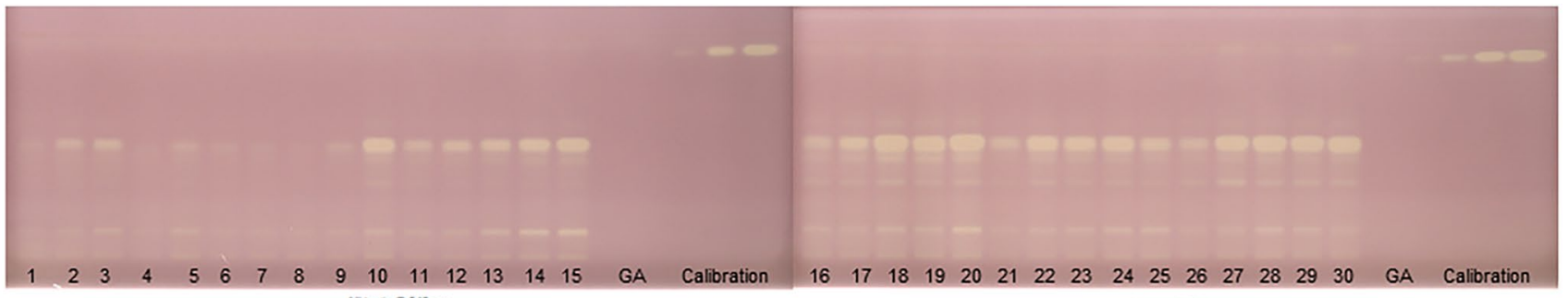

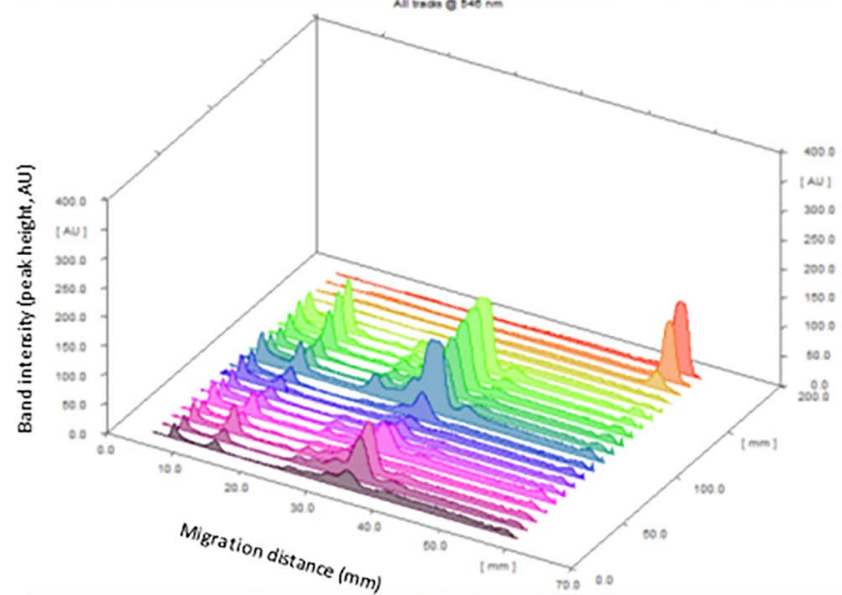

Fig. 2 HPTLC-DPPH autograms (antioxidants as bright bands on purple background) and respective densitograms at $546 \mathrm{~nm}$ for evaluation of the antioxidant activity of the six different Musa spp. accessions elicited by increased sucrose contents (1000 ng/band sample,
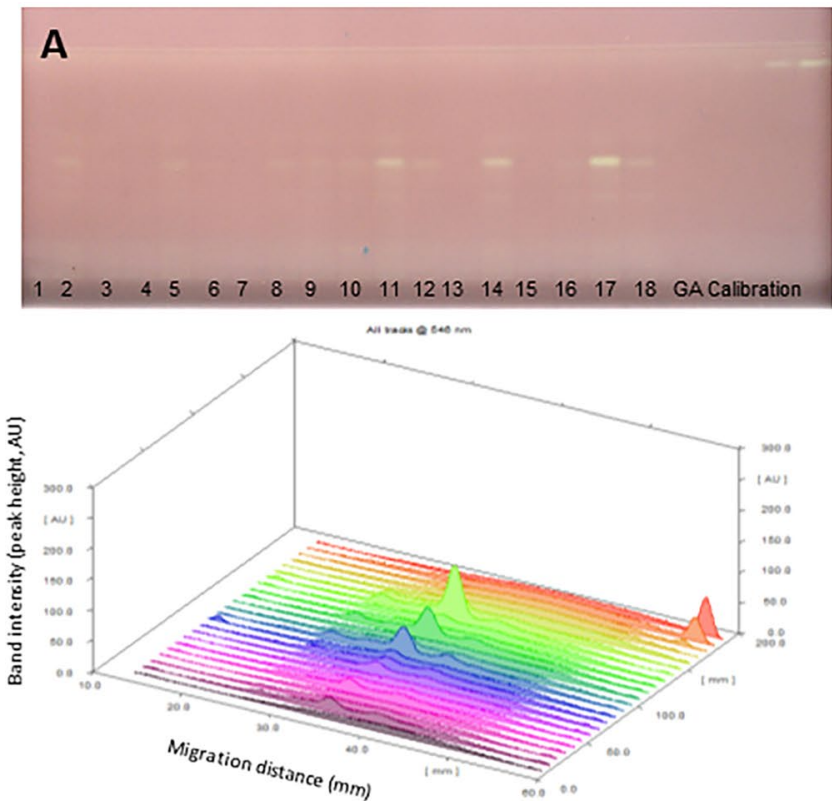

Fig. 3 HPTLC-DPPH autograms (antioxidants as bright bands on purple background) and respective densitograms at $546 \mathrm{~nm}$ for evaluation of the antioxidant activity of the six different Musa spp. accessions elicited by a reduced temperatures (600 ng/band sample, GA calibration levels 3-30 ng/band, detailed information of the track

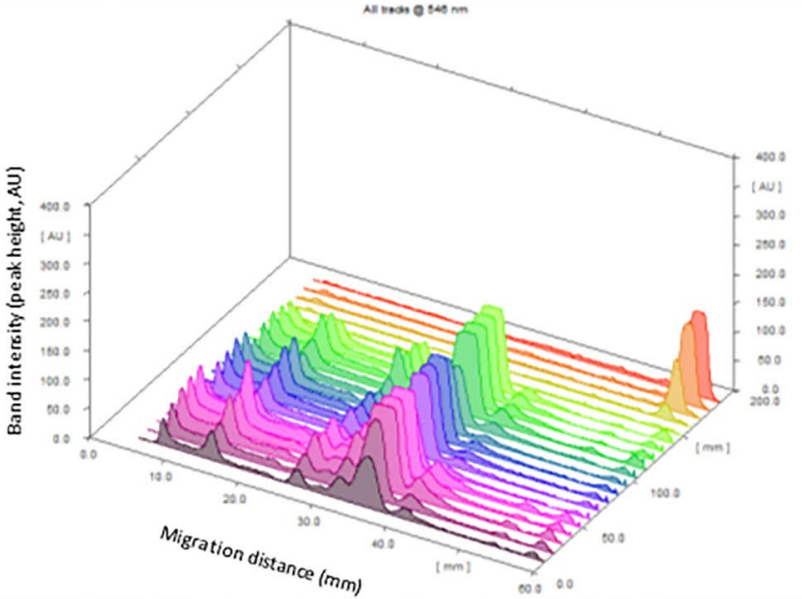

gallic acid (GA) calibration levels $10-100 \mathrm{ng} / \mathrm{band}$, detailed information of the track assignment is found in Table 2), on HPTLC plates silica gel $60 \mathrm{~F}_{254}$ with ethyl acetate-toluene-formic acid-water, 6.8:1:1.4:1
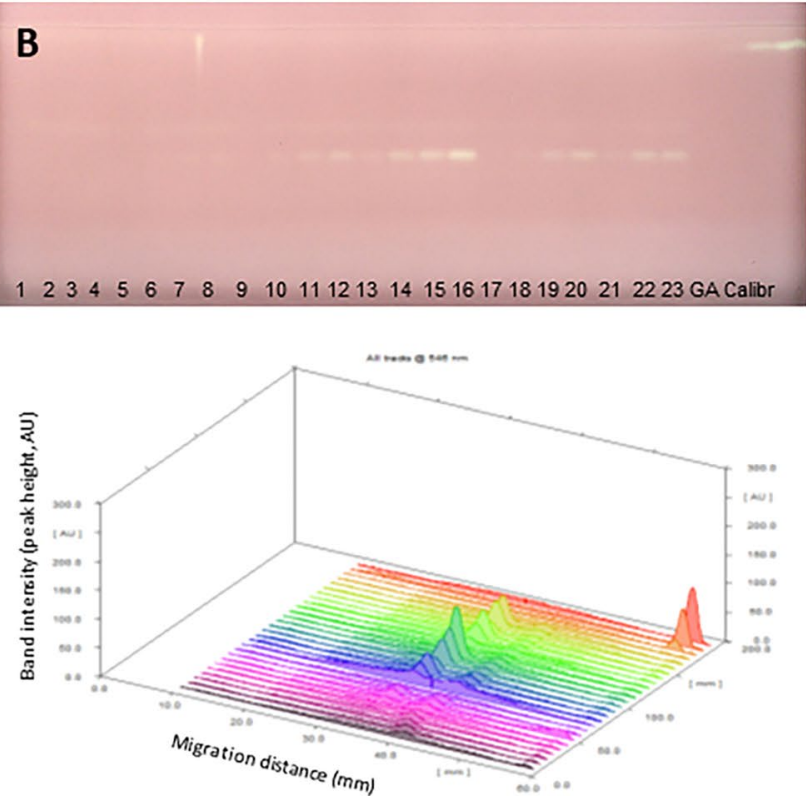

assignment is found in Table 3) and b JA additions (400 ng/band sample, GA calibration levels 5-30 ng/band, detailed information of the track assignment is found in Table 4) on HPTLC plates silica gel $60 \mathrm{~F}_{254}$ with ethyl acetate-toluene-formic acid-water, 6.8:1:1.4:1 
Table 2 Sucrose increase experiment: peak area and TPC obtained by the densitometric measurement and calculated equivalently to gallic acid (GAE) showing the increase in antioxidants compared to the control (set as 1.0; respective highest increase in bold)

\begin{tabular}{|c|c|c|c|c|c|}
\hline ID track & TRC accession & $\begin{array}{l}\text { Sucrose } \\
(\mathrm{g} / \mathrm{L})\end{array}$ & Peak area & $\begin{array}{l}\text { TPC } \\
\text { (ng/g GAE) }\end{array}$ & Increase factor \\
\hline 1 & Simili radjah & 30 & $3167.85 \pm 0.9$ & $36.83 \pm 0.0$ & 1.0 \\
\hline 2 & Simili radjah & 35 & $8271.29 \pm 0.6$ & $70.20 \pm 0.0$ & 1.9 \\
\hline 3 & Simili radjah & 40 & $9942.00 \pm 0.3$ & $81.12 \pm 0.1$ & 2.2 \\
\hline 4 & Simili radjah & 45 & $1989.98 \pm 0.3$ & $29.13 \pm 0.3$ & 0.8 \\
\hline 5 & Simili radjah & 50 & $6341.98 \pm 0.6$ & $57.58 \pm 0.3$ & 1.6 \\
\hline 6 & Foconah & 30 & $3565.71 \pm 0.3$ & $39.43 \pm 0.6$ & 1.0 \\
\hline 7 & Foconah & 35 & $2562.33 \pm 0.3$ & $32.87 \pm 0.6$ & 0.8 \\
\hline 8 & Foconah & 40 & $1874.88 \pm 0.3$ & $28.38 \pm 0.6$ & 0.7 \\
\hline 9 & Foconah & 45 & $5397.44 \pm 0.3$ & $51.41 \pm 0.6$ & 1.3 \\
\hline 10 & Foconah & 50 & $18,737.61 \pm 0.3$ & $138.64 \pm 0.6$ & 3.5 \\
\hline 11 & P. Mas & 30 & $9599.75 \pm 0.6$ & $78.89 \pm 0.6$ & 1.0 \\
\hline 12 & P. Mas & 35 & $12,360.41 \pm 0.3$ & $96.94 \pm 0.6$ & 1.2 \\
\hline 13 & P. Mas & 40 & $14,258.19 \pm 0.3$ & $109.35 \pm 0.6$ & 1.4 \\
\hline 14 & P. Mas & 45 & $16,399.14 \pm 0.3$ & $123.35 \pm 0.3$ & 1.6 \\
\hline 15 & P. Mas & 50 & $17,939.55 \pm 0.3$ & $133.42 \pm 0.3$ & 1.7 \\
\hline 16 & Red Dacca & 30 & $11,523.83 \pm 0.3$ & $68.72 \pm 0.3$ & 1.0 \\
\hline 17 & Red Dacca & 35 & $18,072.33 \pm 0.3$ & $103.42 \pm 0.3$ & 1.5 \\
\hline 18 & Red Dacca & 40 & $25,930.94 \pm 0.3$ & $145.05 \pm 0.3$ & 2.1 \\
\hline 19 & Red Dacca & 45 & $23,575.89 \pm 0.3$ & $132.57 \pm 0.3$ & 1.9 \\
\hline 20 & Red Dacca & 50 & $25,717.73 \pm 0.3$ & $143.93 \pm 0.3$ & 2.1 \\
\hline 21 & Dole & 30 & $13,243.66 \pm 0.7$ & $77.83 \pm 0.3$ & 1.0 \\
\hline 22 & Dole & 35 & $22,095.84 \pm 0.6$ & $124.73 \pm 0.3$ & 1.6 \\
\hline 23 & Dole & 40 & $21,438.37 \pm 0.3$ & $121.25 \pm 0.3$ & 1.6 \\
\hline 24 & Dole & 45 & $23,337.77 \pm 0.3$ & $131.31 \pm 0.3$ & 1.7 \\
\hline 25 & Dole & 50 & $17,093.48 \pm 0.3$ & $98.23 \pm 0.6$ & 1.3 \\
\hline 26 & M. balbisiana $\mathrm{HND}$ & 30 & $12,786.31 \pm 0.3$ & $75.41 \pm 0.6$ & 1.0 \\
\hline 27 & M. balbisiana HND & 35 & $22,985.30 \pm 0.3$ & $129.45 \pm 0.6$ & 1.7 \\
\hline 28 & M. balbisiana HND & 40 & $24,350.91 \pm 0.0$ & $136.68 \pm 0.6$ & 1.8 \\
\hline 29 & M. balbisiana $\mathrm{HND}$ & 45 & $23,131.05 \pm 0.0$ & $130.22 \pm 0.3$ & 1.7 \\
\hline 30 & M. balbisiana $\mathrm{HND}$ & 50 & $23,523.12 \pm 0.3$ & $132.29 \pm 0.3$ & 1.8 \\
\hline
\end{tabular}

*Values are expressed as mean $\pm \operatorname{SEM}(n=3)$ was, the lower was the growth rate. Plants grown at $26^{\circ} \mathrm{C}$ had the highest shoot length, number of leaves and shoots, followed by plants grown at $20{ }^{\circ} \mathrm{C}$. Plants grown at $15{ }^{\circ} \mathrm{C}$ had relatively slower growth rate across all accessions (Fig. 1), except for the average shoot length and shoot number for the accessions P. Mas and Red Dacca, respectively. However, the temperature increase had a reverse effect on the phytochemical accumulation. Reduction in temperature led to an increase in the total phenolic content and antioxidant activity. Extracts of the Musa spp. accessions grown at $26{ }^{\circ} \mathrm{C}$ gave the lowest TPC (Table 3), while more antioxidant bands were observed on extracts of Musa spp. material grown at $20{ }^{\circ} \mathrm{C}$, followed by those grown at $15^{\circ} \mathrm{C}$ (Fig. 3a). The TPC of Simili radjah increased 2.9 times, from 6.3 $\left(26{ }^{\circ} \mathrm{C}\right)$ to $18.5 \mathrm{ng} / \mathrm{g} \mathrm{GAE}\left(20^{\circ} \mathrm{C}\right)$, whereas it increased by 4.8 -fold from $8.6\left(26^{\circ} \mathrm{C}\right)$ to $41.6 \mathrm{ng} / \mathrm{g} \operatorname{GAE}\left(20^{\circ} \mathrm{C}\right)$ for Dole (Table 3). These results showed that $20^{\circ} \mathrm{C}$ was the best concession for both, vegetative growth as well as secondary metabolite production of the studied Musa spp. in vitro plantlets, it allowed the highest antioxidant activity at a moderate growth rate. The highest and lowest temperature are not ideal for natural product production in Musa spp., an intermediate temperature was more optimal for production while plantlets grew better in the highest temperature. This correlation between temperature growth conditions and production of natural production is contrasting with the report made by Ochoa-Villarreal et al. (2016) who stated that the growth of plant cells is inversely related to the production of natural products. Environmental conditions such as light, temperature, humidity are known to affect the phytochemical and secondary metabolite profiles and thus antioxidant activity (Yang et al. 2018). Plants generally adapt to changes in abiotic stresses such as temperature by adjusting their metabolism. Secondary metabolites are also usually produced as a 
Table 3 Temperature of culture conditions reduction experiment: peak area and TPC obtained by the densitometric measurement and calculated equivalently to gallic acid (GAE) showing the increase in antioxidants with regard to control (set as 1.0; respective highest increase in bold)

\begin{tabular}{lllrrl}
\hline ID track & TRC accession & $\begin{array}{l}\text { Temperature } \\
\left({ }^{\circ} \mathrm{C}\right)\end{array}$ & \multicolumn{1}{l}{ Peak area } & \multicolumn{1}{l}{$\begin{array}{l}\text { TPC } \\
(\mathrm{ng} / \mathrm{g} \text { GAE })\end{array}$} & Increase factor \\
\hline 1 & Simili radjah & 26 & $458.91 \pm 0.6$ & $6.30 \pm 0.6$ & 1.0 \\
$\mathbf{2}$ & Simili radjah & $\mathbf{2 0}$ & $\mathbf{2 2 7 1 . 9 5} \pm \mathbf{0 . 6}$ & $\mathbf{1 8 . 4 0} \pm \mathbf{0 . 6}$ & $\mathbf{2 . 9}$ \\
3 & Simili radjah & 15 & $590.12 \pm 0.6$ & $7.19 \pm 0.6$ & 1.1 \\
4 & Foconah & 26 & $342.58 \pm 0.0$ & $5.52 \pm 0.6$ & 1.0 \\
$\mathbf{5}$ & Foconah & $\mathbf{2 0}$ & $\mathbf{1 8 5 1 . 9 6} \pm \mathbf{0 . 3}$ & $\mathbf{1 5 . 6 6} \pm \mathbf{0 . 6}$ & $\mathbf{2 . 8}$ \\
6 & Foconah & 15 & $1480.50 \pm 0.6$ & $13.17 \pm 0.6$ & 2.4 \\
7 & P. Mas & 26 & $561.61 \pm 0.3$ & $6.99 \pm 0.3$ & 1.0 \\
$\mathbf{8}$ & P. Mas & $\mathbf{2 0}$ & $\mathbf{1 9 4 8 . 3 4} \pm \mathbf{0 . 6}$ & $\mathbf{1 6 . 3 1} \pm \mathbf{0 . 3}$ & $\mathbf{2 . 3}$ \\
9 & P. Mas & 15 & $1783.95 \pm 0.6$ & $15.21 \pm 0.3$ & 2.2 \\
10 & Red Dacca & 26 & $2357.17 \pm 0.6$ & $19.06 \pm 0.3$ & 1.0 \\
$\mathbf{1 1}$ & Red Dacca & $\mathbf{2 0}$ & $\mathbf{4 8 3 5 . 1 5} \pm \mathbf{0 . 3}$ & $\mathbf{3 5 . 7 0} \pm \mathbf{0 . 3}$ & $\mathbf{1 . 9}$ \\
12 & Red Dacca & 15 & $2116.89 \pm 0.3$ & $17.44 \pm 0.3$ & 0.9 \\
13 & Dole & 26 & $798.52 \pm 0.3$ & $8.59 \pm 0.3$ & 1.0 \\
$\mathbf{1 4}$ & Dole & $\mathbf{2 0}$ & $\mathbf{5 7 0 8 . 7 5} \pm \mathbf{0 . 3}$ & $\mathbf{4 1 . 5 7} \pm \mathbf{0 . 3}$ & $\mathbf{4 . 8}$ \\
15 & Dole & 15 & $1217.34 \pm 0.6$ & $11.40 \pm 0.3$ & 1.3 \\
16 & M. balbisiana $\mathrm{HND}$ & 26 & $2277.03 \pm 0.3$ & $18.52 \pm 0.3$ & 1.0 \\
$\mathbf{1 7}$ & M. balbisiana $\boldsymbol{H N D}$ & $\mathbf{2 0}$ & $\mathbf{7 2 5 6 . 7 1} \pm \mathbf{0 . 3}$ & $\mathbf{5 1 . 9 7} \pm \mathbf{0 . 3}$ & $\mathbf{2 . 8}$ \\
18 & M. balbisiana $\mathrm{HND}$ & 15 & $3194.43 \pm 0.3$ & $24.68 \pm 0.3$ & 1.3 \\
\hline
\end{tabular}

*Values are expressed as mean $\pm \operatorname{SEM}(n=3)$ defense mechanism against biotic and abiotic stresses (Khare et al. 2020). Several researchers have reported that for plants grown in vitro or on the field, lowering the temperature is able to enhance the accumulation of plant phenolics (Leyva et al. 1995; Janas et al. 2002; Akula and Ravishankar 2011). For example, Melastoma malabathricum cell cultures incubated at a lower temperature range $\left(20 \pm 2{ }^{\circ} \mathrm{C}\right)$ grew better and had higher anthocyanin production than those grown at $26 \pm 2{ }^{\circ} \mathrm{C}$ and $29 \pm 2{ }^{\circ} \mathrm{C}$ (Chan et al. 2010).

\section{Effect of elicitation by JA on antioxidant secondary metabolites}

JA has been used in many plant species for the accumulation of important secondary metabolites such as ginsenoside, vinblastine, nicotine and taxol, among others (Afrin et al. 2015). Hence, the effect of different doses of JA $(50-200 \mu \mathrm{M})$ on plant growth and accumulation of antioxidant compounds in the six Musa spp. accessions was studied. Generally, the addition of different doses of JA affected the plant growth of the accessions differently (Fig. 1). For some accessions (Simili radjah, Foconah and Red Dacca), it was observed that the highest JA dose $(200 \mu \mathrm{M})$ led to longest or equivalent shoot lengths compared to the control (without JA) but the lowest dose $(50 \mu \mathrm{M})$ led to longest shoot length for accessions P. Mas and Dole. But, antioxidant activity and TPC of the Musa spp. accessions increased as JA is added or increased in the culture medium. The highest JA dose $(200 \mu \mathrm{M})$ gave the highest TPC across all accessions (Table 4). Although, there was no qualitative difference in the produced antioxidant compound profile between the control plants and the elicited accessions, a quantitative increase in the TPC and the antioxidant activity was observed for all accessions (Fig. 3b). The TPC of Dole and Musa balbisiana HND was 2.2 and 1.7 times higher than the controls (Table 4). This increase is supported by the study of Jalalpour et al. (2014), which showed that methyl jasmonate $(100 \mu \mathrm{M})$ was able to enhance the accumulation of phenolics and flavonoids in Taxus baccata cell culture. In the same line, the study of Krzyzanowska et al. (2012) detected the highest concentration of rosmarinic acid (1.5 times higher than control) in cell suspension cultures of Mentha piperita after $48 \mathrm{~h}$ of addition of JA at $200 \mu \mathrm{M}$, among the various tested concentrations (50, 100 and $200 \mu \mathrm{M})$. However, Ali et al. (2015) observed that higher doses $(10 \mu \mathrm{M})$ of methyl jasmonate and JA inhibited the accumulation of phenolic compounds in suspension cultures of Artemisia absinthium L. This suggests that the effective dose of an elicitor varies with plant species and can only be determined empirically (Vasconsuelo and Boland 2007). As signaling molecule, JA is known to trigger catalytic reactions by specific enzymes involved in the biosynthesis of phenolic and other antioxidant compounds when a plant is under biotic or abiotic stress (Saeed et al. 2017; Manivannan et al. 2016; Mendoza et al. 2018). 
Table 4 Addition of JA in the Musa spp. culture medium experiment: peak area and TPC obtained by the densitometric measurement and calculated equivalently to gallic acid (GAE) showing the increase in antioxidants with regard to control (set as 1.0; respective highest increase in bold)

\begin{tabular}{|c|c|c|c|c|c|}
\hline ID track & TRC accession & $\begin{array}{l}\text { JA added } \\
(\mu \mathrm{M})\end{array}$ & Peak area & $\begin{array}{l}\text { TPC } \\
\text { (ng/g GAE) }\end{array}$ & Increase factor \\
\hline 1 & Simili radjah & 0 & $508.32 \pm 0.3$ & $7.00 \pm 0.6$ & 1.0 \\
\hline 2 & Simili radjah & 50 & $1138.88 \pm 0.3$ & $9.38 \pm 0.6$ & 1.3 \\
\hline 3 & Simili radjah & 100 & $846.17 \pm 0.3$ & $8.28 \pm 0.6$ & 1.2 \\
\hline 4 & Simili radjah & 200 & $1359.95 \pm 0.3$ & $10.21 \pm 0.6$ & 1.5 \\
\hline 5 & Foconah & 0 & $1244.78 \pm 0.3$ & $9.78 \pm 0.6$ & 1.0 \\
\hline 6 & Foconah & 50 & $1410.15 \pm 0.3$ & $10.40 \pm 0.6$ & 1.1 \\
\hline 7 & Foconah & 100 & $2360.80 \pm 0.6$ & $13.98 \pm 0.6$ & 1.4 \\
\hline 8 & Foconah & 200 & $2301.61 \pm 0.0$ & $13.76 \pm 0.6$ & 1.4 \\
\hline 9 & P. Mas & 0 & $1079.36 \pm 0.3$ & $9.16 \pm 0.6$ & 1.0 \\
\hline 10 & P. Mas & 50 & $1601.44 \pm 0.0$ & $11.12 \pm 0.3$ & 1.2 \\
\hline 11 & P. Mas & 100 & $2878.81 \pm 0.3$ & $15.94 \pm 0.3$ & 1.7 \\
\hline 12 & P. Mas & 200 & $3822.35 \pm 0.3$ & $19.49 \pm 0.3$ & 2.1 \\
\hline 13 & Red Dacca & 0 & $2196.06 \pm 0.3$ & $13.36 \pm 0.3$ & 1.0 \\
\hline 14 & Red Dacca & 50 & $4357.05 \pm 0.3$ & $21.50 \pm 0.0$ & 1.6 \\
\hline 15 & Red Dacca & 100 & $4803.77 \pm 0.3$ & $23.19 \pm 0.0$ & 1.7 \\
\hline 16 & Red Dacca & 200 & $7250.76 \pm 0.3$ & $32.41 \pm 0.6$ & 2.4 \\
\hline 17 & Dole & 0 & $994.66 \pm 0.3$ & $8.84 \pm 0.0$ & 1.0 \\
\hline 18 & Dole & 50 & $1722.59 \pm 0.3$ & $11.58 \pm 0.6$ & 1.3 \\
\hline 19 & Dole & 100 & $2884.76 \pm 0.3$ & $15.96 \pm 0.0$ & 1.8 \\
\hline 20 & Dole & 200 & $3911.28 \pm 0.3$ & $19.82 \pm 0.0$ & 2.2 \\
\hline 21 & M. balbisiana HND & 0 & $1803.31 \pm 0.3$ & $11.88 \pm 0.6$ & 1.0 \\
\hline 22 & M. balbisiana HND & 100 & $3730.04 \pm 0.3$ & $19.14 \pm 0.6$ & 1.6 \\
\hline 23 & M. balbisiana HND & 200 & $3962.59 \pm 0.3$ & $20.02 \pm 0.3$ & 1.7 \\
\hline
\end{tabular}

*Values are expressed as mean $\pm \operatorname{SEM}(n=3)$

\section{Acetylcholinesterase and a-glucosidase inhibitor zones and absence of genotoxic effects}

Acetylcholinesterase and $\alpha$-glucosidase inhibitors are used in the Alzheimer's disease and diabetes mellitus management (Lane et al. 2006; Hanefeld and Schaper 2007), and information on their presence in the studied accessions was of interest. In the HPTLC autograms, enzyme inhibitors were revealed as bright zones on a purple background. In all five selected accessions (that showed high total phenolic content in the different elicitation experiments), two acetylcholinesterase and two $\alpha$-glucosidase inhibiting compound zones were found, when $10 \mu \mathrm{g} / \mathrm{band}$ extract was applied. Acetylcholinesterase was inhibited most intense at $h R_{\mathrm{F}} 42$ but also at $h R_{\mathrm{F}} 28$ (Fig. $4 \mathrm{a}$ ) while $\alpha$-glucosidase most intense inhibition was at $h R_{\mathrm{F}} 34$ but also at $h R_{\mathrm{F}}$ 42 (Fig. B). A recently developed HPTLC-SOS-Umu-C assay (Meyer et al. 2021) was applied to study the presence of potential genotoxic compounds. The same chromatographic HPTLC system was used on RP $18 \mathrm{~W}$ plates, which ensures band sharpness even after $3 \mathrm{~h}$ of incubation in the aqueous bioassay (Klingelhöfer and Morlock 2014). The separated bands were similarly distributed along the migration distance and thus the transfer to the apolar plate was successful (Fig. 4c). The HPTLC-genotoxicity assay showed that there is no genotoxic compound in the elicited Musa spp. accessions for the applied extract amount of $10 \mu \mathrm{g} / \mathrm{band}$.

\section{Conclusions}

The amenability of Musa spp. to plant tissue culturing and elicitation of antioxidants was demonstrated by the results of this study. The antioxidant and phenolic content in Musa spp. can be increased by growing Musa shoot cultures at $20{ }^{\circ} \mathrm{C}$ and adding sucrose at 40 or $45 \mathrm{~g} / \mathrm{L}$ and $\mathrm{JA}$ at $200 \mu \mathrm{M}$. This parameter design was a good compromise between optimum growth and increased secondary metabolite production. The HPTLC-effect directed analysis was exploited to reveal and quantify compounds with antioxidant, anticholinesterase and antidiabetic activities. Such elicitation methods can be further utilized to target the production of important pharmaceuticals. Thus, 

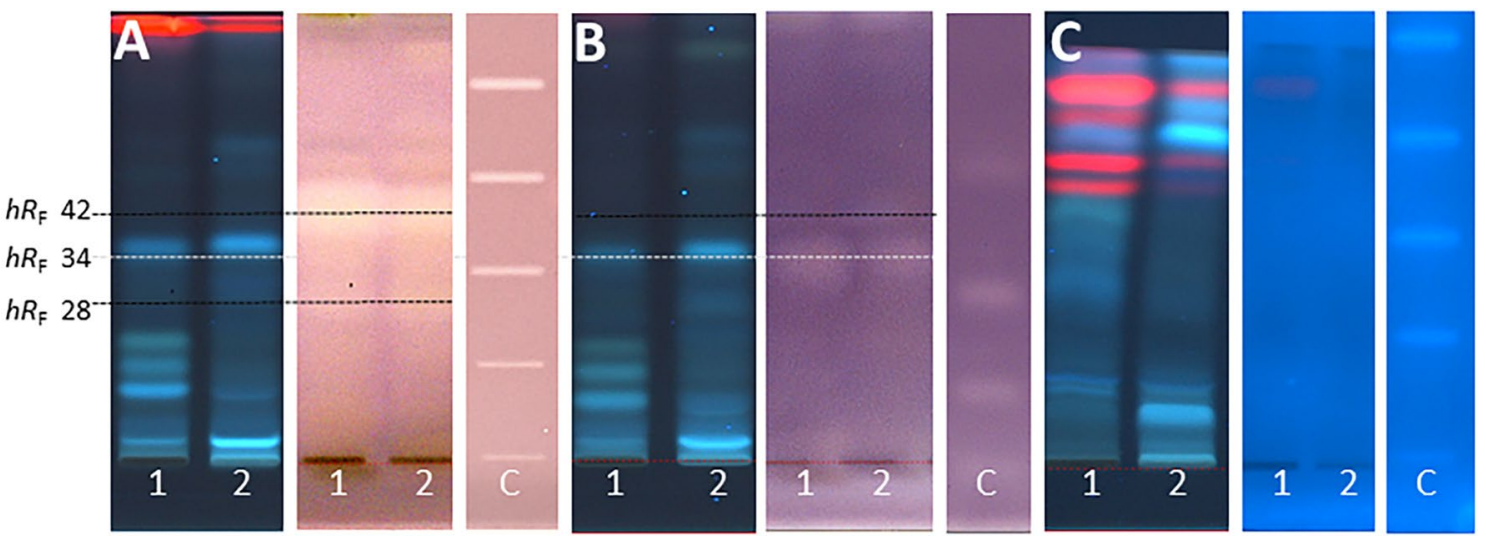

Fig. 4 HPTLC-autograms of the a acetylcholinesterase and b $\alpha$-glucosidase inhibition of the Musa spp. accessions P. Mas grown at $50 \mathrm{~g} / \mathrm{L}$ sucrose (1) and Red Dacca grown at $20{ }^{\circ} \mathrm{C}(2 ; 10 \mu \mathrm{g} / \mathrm{band}$ each; developed as in Fig. 3; documented at FLD 366 nm, and after the assay under white light illumination) as well as c HPTLC-SOS-

in vitro Musa spp. material constitute an alternative system for sustainable, consistent and mass production of plant materials for extraction of antioxidant biochemicals. This system also ensures the rational use of natural resources and reduces the dependence of the pharmaceutical industry on field collection of plant materials thereby conserving natural resources.

Supplementary Information The online version contains supplementary material available at https://doi.org/10.1007/s11240-021-02062-x.

Acknowledgements This research was supported by the German Academic Exchange Service (DAAD) for the short-term research Grant (57378443) given to Ibukun Oluwabukola Ayoola-Oresanya. The authors also thank the Association of African Universities for the small grant for thesis and dissertation given to Ibukun Ayoola- Oresanya and the Food Science group at Justus Liebig University Giessen, especially Nele Hockamp for assisting in part of the experiments.

Author contributions IOO performed most experiments, analyzed the results and drafted the manuscript; MAS was involved in the experimental design; BG designed and supervised the in vitro plant tissue culture elicitation experiments; MTA revised the manuscript; GEM supervised the HPTLC research performed at JLU Giessen and revised the manuscript.

\section{Declarations}

Conflict of interest The authors declare that there are no conflicts of interest.

Open Access This article is licensed under a Creative Commons Attribution 4.0 International License, which permits use, sharing, adaptation, distribution and reproduction in any medium or format, as long as you give appropriate credit to the original author(s) and the source, provide a link to the Creative Commons licence, and indicate if changes were made. The images or other third party material in this article are included in the article's Creative Commons licence, unless indicated
Umu-C assay on RP $18 \mathrm{~W}$ plate at FLD $366 \mathrm{~nm}$ before and after the assay; respective positive control $\mathrm{C}$, applied as track pattern before the assay: physostigmine $(0.1-1.5 \mathrm{ng} / \mathrm{band}$ for a), acarbose (1-10 ng/ band for b) and 4-nitroquinoline-1-oxide (0.1-0.3 ng/band for c)

otherwise in a credit line to the material. If material is not included in the article's Creative Commons licence and your intended use is not permitted by statutory regulation or exceeds the permitted use, you will need to obtain permission directly from the copyright holder. To view a copy of this licence, visit http://creativecommons.org/licenses/by/4.0/.

\section{References}

Abdullah FC, Rahimi L, Zakaria ZA, Ibrahim AL (2014) Hepatoprotective, antiulcerogenic, cytotoxic and antioxidant activities of Musa acuminata peel and pulp. In: Gurib-Fakim A (ed) Novel plant bioresources: applications in food, medicine and cosmetics. Wiley, Chichester. https://doi.org/10.1002/9781118460566.ch26

Afrin S, Huang JJ, Luo ZY (2015) JA-mediated transcriptional regulation of secondary metabolism in medicinal plants. Sci Bull 60(12):1062-1072

Akula R, Ravishankar GA (2011) Influence of abiotic stress signals on secondary metabolites in plants. Plant Signal Behav 6(11):1720-1731

Ali M, Abbasi BH, Ali GS (2015) Elicitation of antioxidant secondary metabolites with jasmonates and gibberellic acid in cell suspension cultures of Artemisia absinthium L. Plant Cell Tissue Organ Cult (PCTOC) 120(3):1099-1106

Ali M, Abbasi BH, Ahmad N, Ali SS, Ali S, Ali GS (2016) Sucroseenhanced biosynthesis of medicinally important antioxidant secondary metabolites in cell suspension cultures of Artemisia absinthium L. Bioprocess Biosyst Eng 39(12):1945-1954

Anand S (2010) Various approaches for secondary metabolite production through plant tissue culture. Pharmacia 1(1):1-7

Ayoola IO, Gueye B, Sonibare MA, Abberton MT (2017) Antioxidant activity and acetylcholinesterase inhibition of field and in vitro grown Musa L. species. J Food Meas Charact 11(2):488-499

Ayoola-Oresanya IO, Sonibare MA, Gueye B, Paliwal R, Abberton MT, Morlock GE (2020) Effect-directed profiling and identification of bioactive metabolites from field, in vitro-grown and acclimatized Musa spp. accessions using high-performance thin-layer chromatography-mass spectrometry. J Chromatogr A 1616:460774. https://doi.org/10.1016/j.chroma.2019.460774 
Azadniya E, Morlock GE (2018) Bioprofiling of Salvia miltiorrhiza via planar chromatography linked to (bio) assays, high resolution mass spectrometry and nuclear magnetic resonance spectroscopy. J Chromatogr A 1533:180-192

Biswas T, Kalra A, Mathur AK et al (2016) Elicitors' influenced differential ginsenoside production and exudation into medium with concurrent $\mathrm{Rg} 3 / \mathrm{Rh} 2$ panaxadiol induction in Panax quinquefolius cell suspensions. Appl Microbiol Biotechnol 100:4909-4922

Chan LK, Koay SS, Boey PL, Bhatt A (2010) Effects of abiotic stress on biomass and anthocyanin production in cell cultures of $\mathrm{Mel}$ astoma malabathricum. Biol Res 43(1):127-35

Cui XH, Murthy HN, Wu CH, Paek KY (2010) Sucrose-induced osmotic stress affects biomass, metabolite, and antioxidant levels in root suspension cultures of Hypericum perforatum L. Plant Cell Tissue Organ Cult (PCTOC) 103(1):7-14

Deepthi S, Satheeshkumar K (2015) Enhanced camptothecin production induced by elicitors in the cell suspension cultures of Ophiorrhiza mungos Linn. Plant Cell Tissue Organ Cult (PCTOC) 124(3):483-493

Dias MI, Sousa MJ, Alves RC, Ferreira IC (2016) Exploring plant tissue culture to improve the production of phenolic compounds: a review. Ind Crop Prod 82:9-22

Drapal M, de Carvalho EB, Rouard M, Amah D, Sardos J, Van den Houwe I, Brown A, Roux N, Swennen R, Fraser PD (2019) Metabolite profiling characterises chemotypes of Musa diploids and triploids at juvenile and pre-flowering growth stages. Sci Rep 9(1):4657

Fazal H, Abbasi BH, Ahmad N (2014) Optimisation of adventitious root culture for production of biomass and secondary metabolites in Prunella vulgaris L. Appl Biochem Biotechnol 174(6):2086-2095

Fazal H, Abbasi BH, Ahmad N, Ali M, Ali S (2016) Sucrose induced osmotic stress and photoperiod regimes enhanced the biomass and production of antioxidant secondary metabolites in shakeflask suspension cultures of Prunella vulgaris L. Plant Cell Tissue Organ Cult (PCTOC) 124(3):573-581

Gueye B, Adeyemi A, Debiru M, Akinyemi B, Olagunju M, Okeowo A, Otukpa S, Dumet D (2012) Standard Operation Procedures (SOP) for IITA in vitro genebank. IITA, Nigeria

Hanefeld M, Schaper F (2007) The role of alpha-glucosidase inhibitors (Acarbose). In: Mogensen CE (ed) Pharmacotherapy of diabetes: new developments. Springer, Boston

Hussain MS, Fareed S, Saba Ansari M, Rahman A, Ahmad IZ, Saeed M (2012) Current approaches toward production of secondary plant metabolites. J Pharm Bioallied Sci 4(1):10-20

Jalalpour Z, Shabani L, Afghani L, Sharifi-Tehrani M, Amini SA (2014) Stimulatory effect of methyl jasmonate and squalestatin on phenolic metabolism through induction of LOX activity in cell suspension culture of yew. Turk J Biol 38(1):76-82

Jamshidi-Aijdi M, Macho J, Müller M, Morlock GE (2019) Effectdirected profiling of aqueous, fermented plant preparations via high-performance thin-layer chromatography combined with in situ assays and high-resolution mass spectrometry. J Liq Relat Technol 42:266-273

Janas KM, Cvikrová M, Pałagiewicz A, Szafranska K, Posmyk MM (2002) Constitutive elevated accumulation of phenylpropanoids in soybean roots at low temperature. Plant Sci 163(2):369-373

Jekayinoluwa T, Gueye B, Bhattacharjee R, Osibanjo O, Shah T, Abberton M (2019) Agromorphologic, genetic and methylation profiling of Dioscorea and Musa species multiplied under three micropropagation systems. PLoS One 14(5):e0216717

Karuppusamy S (2009) A review on trends in production of secondary metabolites from higher plants by in vitro tissue, organ and cell cultures. J Med Plants Res 3(13):1222-1239
Kayani WK, Kiani BH, Dilshad E, Mirza B (2018) Biotechnological approaches for artemisinin production in Artemisia. World J Microbiol Biotechnol 34(4):1-4

Khare S, Singh NB, Singh A, Hussain I, Niharika K, Yadav V, Bano C, Yadav RK, Amist N (2020) Plant secondary metabolites synthesis and their regulations under biotic and abiotic constraints. J Plant Biol 63(3):203-216

Klingelhöfer I, Morlock GE (2014) Sharp-bounded zones link to the effect in planar chromatography-bioassay-mass spectrometry. J Chromatogr A 1360:288-295

Krzyzanowska J, Czubacka A, Pecio L, Przybys M, Doroszewska T, Stochmal A, Oleszek W (2012) The effects of jasmonic acid and methyl jasmonate on rosmarinic acid production in Mentha $\times$ piperita cell suspension cultures. Plant Cell Tissue Organ Cult (PCTOC) 108(1):73-81

Lane RM, Potkin SG, Enz A (2006) Targeting acetylcholinesterase and butyrylcholinesterase in dementia. Int J Neuropsychopharmacol 9(1):101-124

Leyva A, Jarillo JA, Salinas J, Martinez-Zapater JM (1995) Low temperature induces the accumulation of phenylalanine ammonialyase and chalcone synthase mRNAs of Arabidopsis thaliana in a light-dependent manner. Plant Physiol 108(1):39-46

Manivannan A, Soundararajan P, Park YG, Jeong BR (2016) Chemical elicitor-induced modulation of antioxidant metabolism and enhancement of secondary metabolite accumulation in cell suspension cultures of Scrophularia kakudensis Franch. Int J Mol Sci 17(3):399

Mendoza D, Cuaspud O, Arias JP, Ruiz O, Arias M (2018) Effect of salicylic acid and methyl jasmonate in the production of phenolic compounds in plant cell suspension cultures of Thevetia peruviana. Biotechnol Rep 1(19):e00273

Meyer D, Marin-Kuan M, Debon E, Serrant P, Bezançon C, Schilte B, Morlock GE (2021) Detection of low levels of genotoxic compounds in food contact materials using an alternative HPTLCSOS-Umu-C Assay. ALTEX Alternat anim ex. https://doi.org/10. 14573/altex.2006201

Morlock G, Schwack W (2010) Hyphenations in planar chromatography. J Chromatogr A 1217(43):6600-6609

Murashige T, Skoog F (1962) A revised medium for rapid growth andbioassays with tobacco tissue cultures. Physiol Plant 15:473-497

Narayani M, Srivastava S (2017) Elicitation: a stimulation of stress in in vitro plant cell/tissue cultures for enhancement of secondary metabolite production. Phytochem Rev 16(6):1227-1252

Ochoa-Villarreal M, Howat S, Hong S, Jang MO, Jin YW, Lee EK, Loake GJ (2016) Plant cell culture strategies for the production of natural products. BMB Rep 49(3):149

Pauwels L, Inzé D, Goossens A (2009) Jasmonate-inducible gene: what does it mean? Trends Plant Sci 14(2):87-91

Perassolo M, Quevedo CV, Busto VD, Giulietti AM, Talou JR (2011) Role of reactive oxygen species and proline cycle in anthraquinone accumulation in Rubia tinctorum cell suspension cultures subjected to methyl jasmonate elicitation. Plant Physiol Biochem 49(7):758-763

Pi Y, Jiang K, Hou R, Gong Y, Lin J, Sun X, Tang K (2010) Examination of camptothecin and 10-hydroxycamptothecin in Camptotheca acuminata plant and cell culture, and the affected yields under several cell culture treatments. Biocell 34(3):139-143

Rea G, Antonacci A, Lambreva M, Pastorelli S, Tibuzzi A, Ferrari S, Fischer D, Johanningmeier U, Oleszek W, Doroszewska T, Rizzo AM, Berselli PVR, Berra B, Bertoli A, Pistelli L, Ruffoni B, Calas-Blanchard C, Marty JL, Litescu SC, Diaconu M, Touloupakis E, Ghanotakis D, Giardi MT (2011) Integrated plant biotechnologies applied to safer and healthier food production: the Nutra-Snack manufacturing chain. Trends Food Sci Technol 22:353-366 
Rosida, Sukardiman S, Khotib J (2014) The increasing of VEGF expression and re-epithelialisation on dermal wound healing process after treatment of banana peel extract (Musa acuminata Colla). Int J Pharm Pharm Sci 6(11):427-430

Saeed S, Ali H, Khan T, Kayani W, Khan MA (2017) Impacts of methyl jasmonate and phenyl acetic acid on biomass accumulation and antioxidant potential in adventitious roots of Ajuga bracteosa Wall ex Benth., a high valued endangered medicinal plant. Physiol Mol Biol Plants 23(1):229-37

Sharma K, Zafar R (2016) Optimization of methyl jasmonate and $\beta$-cyclodextrin for enhanced production of taraxerol and taraxasterol in (Taraxacum officinale Weber) cultures. Plant Physiol Biochem 1(103):24-30

Sonibare MA, Ayoola IO, Gueye B, Abberton MT, D'Souza R, Kuhnert N (2018) Leaves metabolomic profiling of Musa acuminata accessions using UPLC-QTOF-MS/MS and their antioxidant activity. J Food Meas Charact 12(2):1093-1106

Suan See K, Bhatt A, Lai Keng C (2011) Effect of sucrose and methyl jasmonate on biomass and anthocyanin production in cell suspension culture of Melastoma malabathricum (Melastomaceae). Rev Biol Trop 59(2):597-606

Thakur M, Bhattacharya S, Khosla PK, Puri S (2019) Improving production of plant secondary metabolites through biotic and abiotic elicitation. J Appl Res Med Aroma 12:1-2
Umamaheswari A, Puratchikody A, Prabu SL, Jayapriya T (2017) Phytochemical screening and antimicrobial effect of Musa acuminata bract. Int Res J Pharm 8(8):41-44

Vasconsuelo A, Boland R (2007) Molecular aspects of the early stages of elicitation of secondary metabolites in plants. Plant Sci 172(5):861-875

Vilhena OR, Fachi MM, Marson BM, Dias BL, Pontes FL, Tonin FS, Pontarolo R (2018) Antidiabetic potential of Musa spp. inflorescence: a systematic review. J Pharm Pharmacol 70(12):1583-1595

Wu CH, Dewir YH, Hahn EJ, Paek KY (2006) Optimisation of culturing conditions for the production of biomass and phenolics from adventitious roots of Echinacea angustifolia. J Plant Biol 49(3): 193

Yang L, Wen KS, Ruan X, Zhao YX, Wei F, Wang Q (2018) Response of plant secondary metabolites to environmental factors. Molecules 23(4):762

Publisher's Note Springer Nature remains neutral with regard to jurisdictional claims in published maps and institutional affiliations. 